\title{
Comparison of Ultrasonography and Cystoscopy in the Evaluation of Hematuria
}

\author{
Hematüri Değerlendirilmesinde Ultrasonografi ve Sistoskopinin Karşılaştııılması
}

\author{
(D) Bahadır Topuz, (D) Turgay Ebiloğlu, (D) Engin Kaya, (D) Adem Emrah Çoğuplugil, (D) Mesut Gürdal, (D) Selahattin Bedir, (D) Serdar Yalçın \\ University of Health Sciences, Gülhane Training and Research Hospital, Clinic of Urology, Ankara, Turkiye
}

\section{What's known on the subject? and What does the study add?}

Hematuria is a prevalent symptom and it may be an occult sign of genitourinary abnormality. It is necessary to find the underlying cause of hematuria. In some of patients, malignancy can be detected during the evaluation of hematuria. In this study, we compared the results of ultrasonography and cystoscopy in the evaluation of hematuria. When the literature is examined, there is no study that examines the relationship between the number of red blood cells in urinalysis and the requirement of cystoscopy procedure.

\begin{abstract}
Objective: Every day, many patients visit hospital due to hematuria. Ultrasonography and/or cystoscopy are performed in the initial evaluation and management. In this study, we compared ultrasonography and cystoscopy in the evaluation of microscopic or macroscopic hematuria.

Materials and Methods: A total of 55 patients, who presented to our clinic with the complaint of hematuria between July 2016 and October 2017, were enrolled in this study. After obtaining informed consent, the patients were directed to urinary ultrasonography and cystoscopy for the evaluation of hematuria.

Results: Ultrasonography showed 45 (81.8\%) normal bladder and 10 (18.2\%) masses, and cystoscopy detected 39 (70.9\%) normal bladder and 16 $(29.1 \%)$ masses in the bladder ( $p=0.001)$. Ultrasonography was able to report only $8(50 \%)$ of 16 masses detected via cystoscopy. Two $(20 \%)$ of 10 masses reported by ultrasonography were not confirmed through cystoscopy. The sensitivity and specificity of ultrasonography in detecting and excluding masses in the bladder were calculated to be $50 \%$ and $94.9 \%$, respectively. Ultrasonography failed to detect lesions at the posterior, dome and right side and bladder neck. The cut-off value for blood cell count in urine to refer the patient to a cystoscopy procedure was detected to be 15 with 60\% sensitivity and 50\% specificity.
\end{abstract}

Conclusion: With low sensitivity, ultrasonography could not offer enough knowledge about the bladder masses as sufficient as cystoscopy. Keywords: Cystoscopy, Hematuria, Ultrasonography

$\ddot{0 z}$

Amaç: Birçok hasta her gün hematüri nedeniyle hastaneye gitmektedir. İlk değerlendirme ve yönetimde ultrasonografi ve/veya sistoskopi yapılmaktadır. Bu çalışmada, mikroskopik veya makroskopik hematüri değerlendirilmesinde ultrasonografi ve sistoskopi sonuçları karşılaştırıldı.

Gereç ve Yöntem: Temmuz 2016 ve Ekim 2017 tarihleri arasında, hematüri hastası olan toplam 55 hasta çalışmaya dahil edildi. Hastaların rızası alındıktan sonra hastalar hematüri değerlendirmesinde üriner ultrasonografi ve sistoskopi işlemine yönlendirildi.

Bulgular: Ultrasonografide hastaların $45^{\prime}$ inde $(\% 81,8)$ normal mesane ve 10 'unda $(\% 18,2)$ kitle saptanırken sistoskopide ise hastaların 39 'unda $(\% 70,9)$ normal mesane ve 16 'sında $(\% 29,1)$ mesane içinde kitle saptandı $(p=0,001)$. Ultrasonografi; sistoskopi ile tespit edilen 16 kitlenin sadece 8 'ini (\%50) rapor edebildi. Ultrasonografide rapor edilen 10 kitleden 2'si (\%20) sistoskopi ile doğrulanmadı. Ultrasonografinin mesanedeki kitleleri saptamak ve dışlamak için duyarlıı̆̆ı ve özgüllüğü \%50 ve \%94,9 olarak hesaplandı. Ultrasonografide mesanenin posterior, kubbe, sağ yan duvar ve mesane boynundaki lezyonlar tespit edilemedi. Hastayı bir sistoskopi prosedürüne yönlendirmek için idrardaki eritrosit sayımının kesme değeri \%60 duyarlılık ve \%50 özgüllük ile 15 olarak tespit edildi.

Sonuç: Düşük duyarlılık ile ultrasonografi, sistoskopi kadar mesane kitleleri hakkında yeterli bilgi sağlayamadı.

Anahtar Kelimeler: Sistoskopi, Hematüri, Ultrasonografi

Correspondence: Bahadır Topuz MD, University of Health Sciences, Gülhane Training and Research Hospital, Clinic of Urology, Ankara, Turkiye E-mail: drbtopuz@gmail.com ORCID-ID: orcid.org/0000-0001-6209-803X

Received: 27.09.2018 Accepted: 26.10.2018

Cite this article as: Topuz B, Ebiloğlu T, Kaya E, Çoğuplugil AE, Gürdal M, Bedir S, Yalçın S. Comparison of Ultrasonography and Cystoscopy in the Evaluation of Hematuria. J Urol Surg 2019;6(1):27-31.

Presented in: This study was presented as oral presentation (0-045) at $8^{\text {th }}$ Eurasian Uro-oncology Congress, June $28^{\text {th }}$-July $1^{\text {st }} 2018$, Tbilisi, Georgia.

๑Copyright 2019 by the Association of Urological Surgery / Journal of Urological Surgery published by Galenos Publishing House. 


\section{Introduction}

Hematuria is a common clinical finding and it can be a sign or symptom of an important disease in the practice of urology. The prevalence of hematuria is variable but estimated at 2.5\% to $20 \%$ in the adult patients (1). Hematuria is described as the presence of an abnormal number of red blood cells (RBCs) in a urine sample and it can be classified as microscopic or macroscopic (gross) hematuria (2). According to the latest American Urological Association guidelines, microscopic hematuria can be defined as more than 3 RBCs per high-power field (hpf) in a properly collected urine sample (3). In most cases of microscopic hematuria, there is no etiology or pathology and this condition is called as asymptomatic microscopic hematuria with a prevalence ranging from $0.9 \%$ to $18.0 \%(3,4)$. There are many causes for microscopic hematuria, but the most common pathologies include urinary tract infection, benign prostatic enlargement, urolithiasis, urethral stricture disease, urologic malignancy, renal cystic disease, and renal disease $(3,4,5)$. Male gender, age over 35 years, smoking history, analgesic abuse, and exposure to chemicals are the most common risk factors for urinary tract malignancy in patients with microscopic hematuria (5). Macroscopic hematuria can be described as a visible discoloration due to the presence of blood in the urine (2). In the diagnosis of macroscopic hematuria, the use of various medicines and foods that discolor urine should be investigated.

A detailed history should be taken in patients presenting with hematuria. Tobacco and anticoagulant drug use should be questioned. A physical examination involving the urogenital system should be performed. All patients are evaluated with whole blood count, renal function tests, urine analysis, and urine culture. Intravenous urography has been used to evaluate microscopic hematuria in the past, but now it is not preferred due to its low sensitivity (3). Ultrasonography (USG), computed tomographic urography and magnetic resonance imaging are more frequently preferred because they provide detailed images in the evaluation of microscopic hematuria $(3,5)$. Upper urinary tract can be examined by radiological methods but cystoscopy should be done especially for lower urinary tract evaluation (1). Cystoscopy should be recommended to hematuria patients with risk factor for urinary system malignancy, such as male gender, age over 35 years, and tobacco use $(3,6)$. Although cystoscopy is an invasive procedure, it continues to be a reference standard in the evaluation of patients with asymptomatic microscopic hematuria (7). USG is considered the imaging method of choice for hematuria and it has an indisputable role in the evaluation of hematuria. Since contrast media and radiation are not applied during USG, it is a less risky diagnostic method for hematuria patients (2).
Every day, many patients visit hospital due to hematuria. In some of these patients, malignancy can be detected during the evaluation of hematuria. USG and/or cystoscopy are performed in the initial evaluation and management. In this study, we compared USG and cystoscopy in the evaluation of microscopic or macroscopic hematuria.

\section{Materials and Methods}

\section{Patient Selection}

This study was approved by the Gülhane Training and Research Hospital Ethical Committee (approval number: 18/88, date: 5 April 2018) and followed the Institutional Review Board for Human Subjects Researches Guidelines.

This is a retrospective study. The sample size was calculated with the help of sample size calculator at www.calculator.net and examining $>50$ patients were found to be enough for this study. A total of 55 patients who presented to our clinic with the complaint of hematuria between July 2016 and October 2017 were enrolled in this study. The patients, who were included in the study, had no history of upper urinary tract or bladder malignancy. After obtaining informed consent, the patients were directed to urinary USG and cystoscopy for the evaluation of hematuria.

All patients underwent a complete physical examination especially for costovertebral tenderness. After physical examination, all patients were evaluated by urinalysis, urine culture, measurement of hemoglobin, serum urea and creatinine, and kidneys, ureters, and bladder (KUB) X-ray. Patients, who had positive urine cultures, were treated according to the reported antibiogram results until the urine cultures became sterile. All procedures were done when the urine cultures were sterile. A second urinalysis was taken for the presence of blood and to investigate white cell count in the urine after sterile urine culture was obtained. Firstly, urinary system USG was used for diagnosis. Then, cystoscopy was applied to investigate any mass in the bladder. Patients with negative urine cultures had a single-dose oral antibiotic with a first-generation cephalosporin or quinolone for cystoscopy procedures.

\section{Statistical Analysis}

Statistical analysis was done using Statistical Package for Social Sciences 20.0 software (SPSS 20.0 for MAC). Descriptive statistics of nominal samples were expressed with numbers and percentiles. Descriptive statistics of scale samples were expressed as mean \pm standard deviation (minimum-maximum). The Shapiro-Wilk test and Kurtosis and Skewness test were used to assess normality of the variables. Cross-tabs were used to detect sensitivity and specificity. A chi-square test was used 
to compare the independent nominal parameters. The paired samples t-test was used to compare the independent scale parameters with normal distribution. A p value of less than 0.05 was considered statistically significant.

\section{Results}

Of 55 patients included in the study, 39 (70.9\%) were female and $16(29.1 \%)$ were male. The mean age of the patients was $62.43 \pm 14.79$ (21-91) years. Nine patients (16.3\%) had a history of tobacco smoking at the time of interview. None of the patients had costovertebral tenderness. The mean hemoglobin, urea, and creatinine levels were $12.9 \pm 1.5(10.50-16.73) \mathrm{g} /$ $\mathrm{dL}, 30.43 \pm 5.3(17-48) \mathrm{mg} / \mathrm{dL}$, and $1.07 \pm 0.2(0.74-1.79) \mathrm{mg} / \mathrm{dL}$, respectively. Thirty-two patients had urinary infection at first visit, and they were treated according to antibiogram results. None of our patients had active urinary tract infections, and urine samples and urine cultures were normal before USG and cystoscopy procedures. The mean blood and white cell count, when the urine culture, was sterile was $82.23 \pm 62(0-1249)$ and $15.81 \pm 13.2(0-364)$, respectively.

USG reported $45(81.8 \%)$ normal bladder, and 10 (18.2\%) masses; and cystoscopy detected 39 (70.9\%) normal bladder, and $16(29.1 \%)$ masses in the bladder $(p=0.001)$. USG was able to report only $8(50 \%)$ of 16 masses detected by cystoscopy. Two (20\%) of 10 masses reported by USG were not confirmed

Table 1. Lesions in cystoscopy and ultrasonography

\begin{tabular}{|c|c|c|c|c|c|}
\hline & & & \multicolumn{3}{|c|}{ Lesions in USG } \\
\hline & & & \multirow[b]{2}{*}{ Total } & No & Yes \\
\hline & & & & $\begin{array}{l}\text { Count } \\
(\%)\end{array}$ & $\begin{array}{l}\text { Count } \\
(\%)\end{array}$ \\
\hline \multirow{3}{*}{$\begin{array}{l}\text { Lesions in } \\
\text { cystoscopy }\end{array}$} & No & Count (\%) & 37 (94.9) & $2(5.1)$ & 39 \\
\hline & Yes & Count (\%) & $8(50.0)$ & $8(50.0)$ & 16 \\
\hline & Total & & 45 (81.8) & 10 (18.2) & 55 \\
\hline
\end{tabular}

via cystoscopy (Table 1). The sensitivity and specificity of USG to detect and exclude masses in the bladder were calculated to be $50 \%$ and $94.9 \%$, respectively. The positive and negative likelihood ratios of USG to detect masses in the bladder were 8.3 and 0.53 , respectively. There was a statistically significant difference in examining the location of the lesions in the bladder between USG and cystoscopy $(p=0.001)$. USG failed to detect lesions at the posterior, dome, and right side, and bladder neck (Table 2). The mean lesion diameter detected by USG and

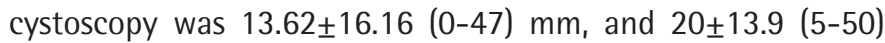
$\mathrm{mm}$, respectively $(\mathrm{p}=0.007)$.

Calculating the receiver operating characteristic curve using the blood cell count in urine sample, there was a 0.534 area under curve value. This meant that blood cell count in urine sample could be a moderately (not very useful) used parameter for the diagnosis of any lesion in the bladder (Figure 1). The

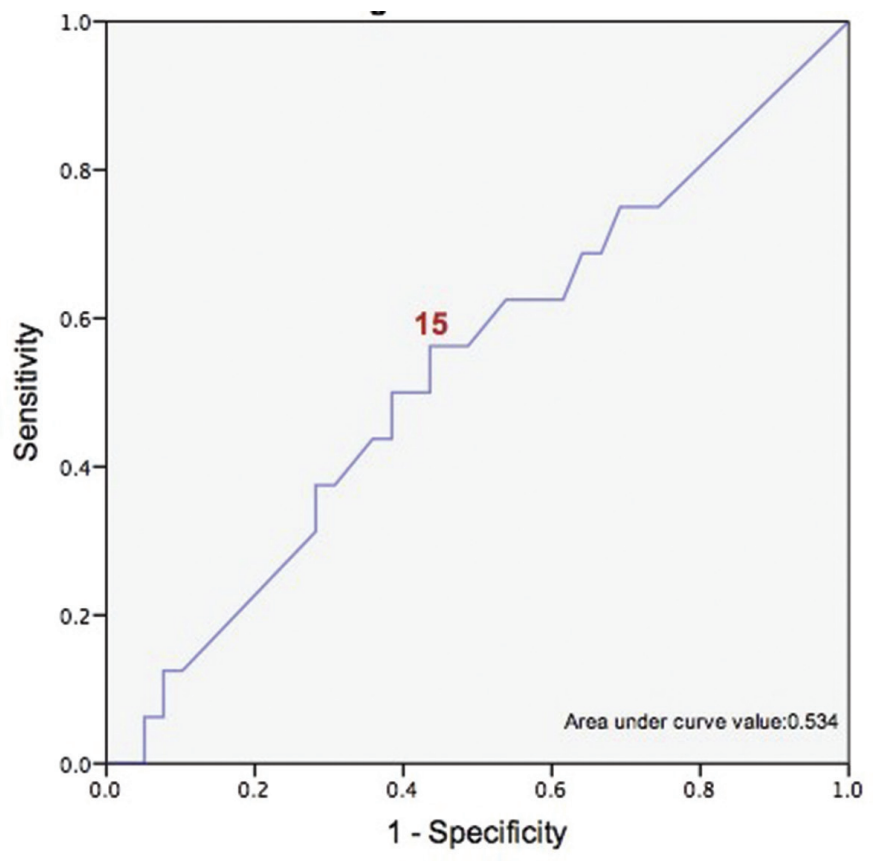

Figure 1. Receiver operating characteristic curve using urine blood cell count

Table 2. Localization of lesions in ultrasonography and cystoscopy

\begin{tabular}{|c|c|c|c|c|c|c|c|c|c|}
\hline & & \multicolumn{7}{|c|}{ Localization of lesions in cystoscopy } & \multirow{2}{*}{ Tota } \\
\hline & & No & Trigon & Posterior & Dome & Right side & Left side & Bladder neck & \\
\hline \multirow{7}{*}{$\begin{array}{l}\text { Localization } \\
\text { of lesions in } \\
\text { ultrasonography }\end{array}$} & No & 37 & 0 & 1 & 1 & 4 & 0 & 2 & 45 \\
\hline & Trigon & 1 & 0 & 0 & 0 & 0 & 0 & 0 & 1 \\
\hline & Posterior & 1 & 0 & 2 & 0 & 0 & 0 & 0 & 3 \\
\hline & Dome & 0 & 0 & 0 & 0 & 0 & 0 & 0 & 0 \\
\hline & Right side & 0 & 0 & 0 & 0 & 2 & 0 & 0 & 2 \\
\hline & Left side & 0 & 0 & 0 & 0 & 0 & 4 & 0 & 4 \\
\hline & Bladder neck & 0 & 0 & 0 & 0 & 0 & 0 & 0 & 0 \\
\hline Total & & 39 & 0 & 3 & 1 & 6 & 4 & 2 & 55 \\
\hline
\end{tabular}


cut-off value for blood cell count in urine to refer the patient to a cystoscopy procedure was detected to be 15 with $60 \%$ sensitivity and 50\% specificity.

\section{Discussion}

Hematuria is a prevalent symptom and it may be an occult sign of genitourinary abnormality. This finding sometimes presents as a symptom but it can also be detected incidentally. It is necessary to find the underlying cause. Hematuria is described as the presence of RBCs that are visible in the urine (macroscopic hematuria) or directly detected by microscopy (microscopic hematuria) (8). Hematuria can be defined as $\geq 3 \mathrm{RBCs}$ per (hpf2) and $\geq 5 \mathrm{RBCs} / \mathrm{hpf} 3$ in urine sample $(3,8)$. Hematuria can be classified as nephrological (glomerular disease) or urological (tumors, urinary tract infection, stone disease, benign prostatic enlargement, urethral caruncle, meatal ulcers, trauma) in origin $(3,4,5,8)$. Sometimes microscopic hematuria can also occur with an excessive exercise when there is no underlying cause (9). Based on biochemical and radiological studies, we decided that the case in our study was hematuria of urological origin. Since the risk of urinary system malignancy is relatively low in young people, the prevalence of an important underlying pathology for hematuria is low and it ranges between 0 and 7.2\% (10). In this age group, hematuria related to nephrologic causes is more common than that of urological origin. Along with advancing age, the risks for important diseases also increase (8). Risk factors for significant diseases in patients with microscopic hematuria include male gender, age over 35 years, smoking history, analgesic abuse, exposure to chemicals (benzenes or aromatic amines), history of gross hematuria, history of urological disease, history of urinary tract infection, and history of pelvic irradiation $(3,5,8)$. Macroscopic hematuria is more closely related to the underlying serious urological diseases (8). In our study, we performed cystoscopy for all patients with macroscopic hematuria. On the other hand, we performed cystoscopy by questioning of the risk factors for microscopic hematuria. All these patients had risk factors for microscopic hematuria.

Different radiological diagnostic methods are used to detect this abnormality such as KUB X-ray, intravenous pyelography, USG, computed tomography, computed tomographic urography and magnetic resonance imaging $(3,5)$. The important thing is to find the underlying cause of hematuria with some of these imaging methods, not all of them. Although cystoscopy is an invasive procedure, it is an endoscopic method that allows direct observation of the urethra, prostate, and the bladder (11). The procedure can be performed using rigid or flexible cystoscopy, but rigid cystoscopy is more traumatic (11). Tissue biopsy may be done during cystoscopy. Cystoscopy is recommended in patients with a risk of malignancy in the urinary system (6).
Radiological methods should be accompanied by cystoscopy in the evaluation of hematuria because in most cases, it has been determined that the lower urinary tract pathologies were the cause of bleeding (12). There is no radiologic method which shows the cause of the hematuria in the lower urinary tract as good as cystoscopy (12). Therefore, cystoscopy was performed after sonographic evaluation in all patients who presented with hematuria in our study. In some patients, a mass in the bladder was detected only by cystoscopy. In a study published in 2008, it has been reported that the sensitivity and specifity of USG were $50 \%$ and $95 \%$, respectively (13). In a study published in 2002, the sensitivity and specifity of of USG in detecting bladder masses in patients who were admitted with hematuria were reported to be $63 \% 99 \%$, respectively (14). In our study, we found that the sensitivity and specificity of USG in detecting bladder cancer were $50 \%$ and $94.9 \%$, respectively. These results are compatible with the literature data.

Anticoagulant medication use at the therapeutic doses does not cause hematuria, thus, urologic problems should be investigated for hematuria etiology in these patients $(12,15)$. We questioned the use of anticoagulant medication before the diagnostic methods in patients who presented with hematuria. We found that the international normalized ratio was within the normal limits. We did not consider the use of anticoagulant medication as the cause of hematuria.

When the literature is examined, there is no study that examines the relationship between the number of RBCs in urinalysis and the requirement of cystoscopy procedure. It was determined that the number of RBCs in urinalysis was $15 \mathrm{RBCs} / \mathrm{hpf} 2$ for the requirement of cystoscopy.

\section{Study Limitations}

The small number of patients may be the main limitation of the study. Further studies with a larger sample size would provide more reliable results.

\section{Conclusion}

With low sensitivity, USG could not offer enough knowledge about bladder masses as sufficiently as cystoscopy.

\section{Ethics}

Ethics Committee Approval: This study was approved by the Gülhane Training and Research Hospital Ethical Committee (approval number: 18/88, date: 05 April 2018).

Informed Consent: Consent form was filled out by all participants.

Peer-review: Externally peer-reviewed. 


\section{Authorship Contributions}

Surgical and Medical Practices: B.T., T.E., M.G., Concept: T.E., E.K., M.G., Design: S.Y., A.E.Ç., S.B., Data Collection or Processing: B.T., T.E., Analysis or Interpretation: M.G., S.B., Literature Search: B.T., S.Y., Writing: B.T., T.E.

Conflict of Interest: No conflict of interest was declared by the authors.

Financial Disclosure: The authors declared that this study received no financial support.

\section{References}

1. Margulis V, Sagalowsky Al. Assessment of hematuria. Med Clin North Am 2011;95:153-159.

2. Jimbo M. Evaluation and management of hematuria. Prim Care 2010;37:461472

3. Davis $\mathrm{R}$, Jones JS, Barocas DA, Castle EP, Lang EK, Leveillee RJ, Messing EM, Miller SD, Peterson AC, Turk TM, Weitzel W. Diagnosis, evaluation and follow-up of asymptomatic microhematuria (AMH) in adults: AUA guideline. J Urol 2012;188(Suppl 6):2473-2481.

4. Richards KA, Ruiz VL, Murphy DR, Downs TM, Abel EJ, Jarrard DF, Singh H. Diagnostic evaluation of patients presenting with hematuria: An electronic health record-based study. Urol Oncol 2018;36:88.

5. Sharp VJ, Barnes KT, Erickson BA. Assessment of asymptomatic microscopic hematuria in adults. Am Fam Physician 2013;88:747-754.

6. David SA, Patil D, Alemozaffar M, Issa MM, Master VA, Filson CP. Urologist Use of Cystoscopy for Patients Presenting With Hematuria in the United States. Urology 2017;100:20-26.
7. Schmitz-Drager BJ, Kuckuck EC, Zuiverloon TC, Zwarthoff EC, Saltzman A, Srivastava A, Hudson MA, Seiler R, Todenhöfer T, Vlahou A, Grossman HB, Schoenberg MP, Sanchez-Carbayo M, Brünn LA, van Rhijn BW, Goebell PJ, Kamat AM, Roupret M, Shariat SF, Kiemeney LA. Microhematuria assessment an IBCN consensus-Based upon a critical review of current guidelines. Urol Oncol 2016;34:437-451.

8. Rodgers M, Nixon J, Hempel S, Aho T, Kelly J, Neal D, Duffy S, Ritchie G, Kleijnen J, Westwood M. Diagnostic tests and algorithms used in the investigation of haematuria: systematic reviews and economic evaluation. Health Technol Assess 2006:10.

9. Jones GR, Newhouse IJ, Jakobi JM, LaVoie NL, Thayer R. The incidence of hematuria in middle distance track running. Can J Appl Physiol 2001;26:336349.

10. Benbassat J, Gergawi $M$, Offringa $M$, Drukker A. Symptomless microhaematuria in schoolchildren: causes for variable management strategies. OJM 1996;89:845-854.

11. Yeoh M, Lai NK, Anderson D, Appadurai V. Macroscopic haematuria--a urological approach. Aust Fam Physician 2013;42:123-126.

12. McDonald MM, Swagerty D, Wetzel L. Assessment of microscopic hematuria in adults. Am Fam Physician 2006;73:1748-1754.

13. El-Galley R, Abo-Kamil R, Burns JR, Phillips J, Kolettis PN. Practical use of investigations in patients with hematuria. J Endourol 2008;22:51-56.

14. Datta $S N$, Allen GM, Evans R, Vaughton KC, Lucas MG. Urinary tract ultrasonography in the evaluation of haematuria--a report of over 1,000 cases. Ann R Coll Surg Engl 2002;84:203-205.

15. Keeling D, Baglin T, Tait C, Watson H, Perry D, Baglin C, Kitchen S, Makris M. Guidelines on oral anticoagulation with warfarin - fourth edition. Br J Haematol 2011;154:311-324. 